Submission: 30.07.2018 Accepted: 09.09.2018 Published Online: 17.09.2018

\title{
Molecular Characterization of Demodex Canis (Acarina: Demodicidae) in Domestic Dogs (Canis Familiaris)
}

\author{
Gökmen Zafer PEKMEZCí1*, Didem PEKMEZCİ², Cenk Soner BOLUKBAS ${ }^{3}$ \\ ${ }^{1}$ Department of Preclinical Science, Faculty of Veterinary Medicine, Ondokuz Mayis University, Samsun 55139, Turkey \\ ${ }^{2}$ Department of Internal Medicine, Faculty of Veterinary Medicine, Ondokuz Mayis University, Samsun 55139, Turkey \\ ${ }^{3}$ Department of Parasitology, Faculty of Veterinary Medicine, Ondokuz. Mayis University, Samsun 55139, Turkey
}

\#This study was presented in $1^{\text {st }}$ International Eurasian Conference on Biological and Chemical Sciences (EurasianBioChem 2018) 26-27 April 2018, Ankara/Turkey

*Corresponding author e-mail: zpekmezci@omu.edu.tr

\begin{abstract}
Canine demodicosis (CD) is an inflammatory skin disease caused by excessive proliferation of Demodex mites (Acarina: Demodicidae) former in the dogs' follicles latter in the sebaceous glands. To date Demodex canis, D. injai, and D. cornei are the three Demodex species that recognized in the domestic dog Canis familiaris. There are reports of morphological identification of Demodex spp. from pet dogs in Turkey. Nevertheless there had been no reports of characterizing the Demodex mite from pet dogs in Turkey using well-defined mitochondrial DNA gene sequences. The aim of the present study is to reveal first molecular characterization data on D. canis infesting domestic dogs (Canis familiaris) in Turkey. Demodex mites were obtained from skin scrapings of dogs with $\mathrm{CD}$ and identified microscopically as $D$. canis. The mitochondrial DNA 12S (mtDNA 12S) rRNA gene amplified, sequenced and compared with available Demodex sequences in Genbank using BLAST analyses. D. canis isolate (DP-Samsun, MH374631) obtained in the study matched $100 \%$ (474/474) with previously reported gene sequences for the 12S rRNA of mtDNA in D. canis (KX264486, isolate Demo.can2) from dogs in China. Pairwise comparison between the $12 \mathrm{~S}$ rRNA sequences of the $D$. canis from Turkey (MH374631) and other mtDNA rRNA gene of D. canis isolates from China (KX264486-88) presented differences ranging from 0.0 to $0.6 \%$. In conclusion, within the present study, we provided the molecular characterization of $D$. canis in domestic dogs for the first time by sequencing of the partial mtDNA in Turkey.
\end{abstract}

Keywords: Demodex canis, Dog, Molecular characterization, PCR, Sequencing.

\section{Evcil Köpeklerde (Canis Familiaris) Demodex Canis'in (Acarina: Demodicidae) Moleküler Karakterizasyonu}

ÖZ

Kanin demodikozis (KD) Demodex akarlarının (Acarina: Demodicidae) kıl köklerinde ve yağ bezlerinde aşırı çoğalmasının neden olduğu inflamatuar bir deri hastalığıdır. Bugüne kadar evcil köpeklerde Canis familiaris bildirilen üç Demodex türü $D$. canis, D. injai ve D. cornę'dir. Türkiye'de pet köpeklerinde Demodex spp.'nin morfolojik identifikasyonu ile ilgili raporlar vardır. Buna rağmen Türkiye'de evcil köpeklerde Demodex akarlarının iyi tanımlanmış mitokondriyal DNA gen sekanslarının moleküler karakterizasyonu ile ilgili raporlar yoktur. Bu çalışmanın amacı Türkiye'de evcil köpeklerde (Canis familiaris) D. canis üzerine ilk moleküler karakterizasyon verilerini ortaya çıkarmaktır. Demodex akarlar1 KD'li köpeklerin deri kazıntılarından elde edildi ve mikroskobik incelemeler ile $D$. canis olarak teşhis edildi. Mitokondriyal DNA'nın $12 S$ rRNA geni çoğaltıldı, sekanslandı ve Genbank'ta BLAST analizleriyle mevcut bilinen Demodex sekansları ile karşılaştırıldı. Araştırmada elde edilen D. canis izolatı (DP-Samsun, MH374631) Çin'de daha önce köpeklerde rapor edilen D. canis $12 \mathrm{~S}$ rRNA gen sekans1 (KX264486, Demo.can2) ile \% 100 (474/474) olarak eşleşti. Türkiye'den D. canis'in 12S rRNA dizisi (MH374631) ile Çin'den rapor edilmiş D. canis izolatlarının (KX264486-88) 12S rRNA sekansları arasındaki ikili hizalama analizleri \% 0,0 ile \% 0,6 arasında değişen farklılıkları ortaya çıkarmıştır. Sonuç olarak bu araştırma ile Türkiye’de ilk kez evcil köpeklerde D. canis türünün moleküler karakterizasyonu mitokondriyal DNA sekansları kullanarak sağlandı.

Anahtar Kelimeler: Demodex canis, DNA dizileme, köpek, moleküler karakterizasyon, PZR. 


\section{INTRODUCTION}

Canine demodicosis (CD) is an inflammatory skin disease caused by excessive proliferation of Demodex mites (Acarina: Demodicidae) in the hair follicles and sebaceous glands. There are three recognized canine Demodex mites and these species are $D$. canis, D. injai, and D. cornei in domestic dog Canis lupus familiaris (L.). Demodex canis is the main causative agent of CD (Scott et al. 2001, Izdebska and Rolbiecki 2018).

Despite CD is a well-known challenging problem in veterinary medicine, little is known about the phylogenetic relationships of this demodecid (Silbermayr et al. 2015). Mitochondrial genes have been successfully applied in order to carry out phylogenetic and taxonomic works in various taxa of mites (Simon et al. 1994). The rapid advances in molecular techniques support a usefull technical achievement for the molecular characterization of Demodex at a genetic level (Hu et al. 2017). The mitochondrial (mtDNA) $16 \mathrm{~S}$ has been used for molecular characterization of the Demodecid mite (Frank et al. 2013, Zhao et al. 2013, Silbermayr et al. 2015, Sastre et al. 2016) and mt-cox1 (De et al. 2012, Zhao et al. 2014). Moreover, mitochondrial $12 S$ was recently found more applicable than other DNA barcoding gene (cox1 and 16S) for molecular characterization of Demodecid mites at genus or species level (Hu et al. 2017).

In Turkey, there are reports of morphological identification of Demodex spp. from pet dogs (Deger et al. 1994, Beyazit et al. 2010, Maden et al. 2012, Pekmezci et al. 2014). To date there had been no reports of characterizing the Demodex mite from pet dogs in Turkey using well-defined mtDNA gene sequences.

The aim of the present study is to describe first molecular characterization of $D$. canis in domestic dogs (Canis familiaris) in Turkey.

\section{MATERIAL and METHODS}

\section{Parasitological examinations, DNA extraction and PCR Analysis}

Demodex mites were obtained from skin scrapings of dogs which brought to the Veterinary Teaching and Animal Hospital, of the Faculty of Veterinary Medicine, University of Ondokuz Mayis, in April 2017 to December 2017 diagnosed as CD in Turkey. Demodex mites were primarily identified microscopically and classified as $D$. canis. The parasites were collected by using a micropipette and added to $50 \mu \mathrm{l}$ of ethanol. Genomic DNA (gDNA) was extracted from polled mites using a commercial kit (Genejet, Thermo Scientific). The mitochondrial $12 \mathrm{~S}$ rRNA gene was selected to molecular identification of Demodex species. The mtDNA $12 \mathrm{~S}$ was amplified using 12S-F (CTACTTTGTTACGACT'TAT'TTTA) and 12S-R (GCCAGCAGT'TTCGGTTA) (Hu et al. 2017). The PCR conditions followed the protocol described by Cheng et al (2015). PCR amplicons were visualized on $1 \%$ agarose gel by UV transillumination.

\section{DNA sequencing and molecular analysis}

DNA sequencing was performed by Macrogen Inc. (Amsterdam, NL) for mtDNA 12S gene. Sequences quality was checked using Geneious R11 (Biomatters Ltd) (Kearse et al. 2012). Later, obtained sequences were confirmed by both comparisons, assembled and edited with using Geneious R11 (Biomatters Ltd) (Kearse et al. 2012). The consensus sequences were compared with those previously published data for molecular identification by using the BLAST within the GenBank database (Altschul et al. 1990) and aligned with those previously characterized sequences of $D$. canis using ClustalW in Mega 7.0 multiple sequence alignments (Thompson et al. 1994). Nucleotide composition was calculated using Bioedit (Hall 1999). Genetic distances were calculated using the Kimura two-parameter model with pairwise deletion in Mega 7.0 (Kumar et al. 2016). Molecular analyses were carried out comparatively according to sequences obtained in previous studies in Genbank (Hu et al. 2017).

\section{RESULTS}

In the present study, Demodex canis was microscopically identified from dogs (Figure 1). The amplification of the mtDNA 12S RNA gene produced a fragment of approximately $500 \mathrm{bp}$. The mtDNA PCR product was subjected to direct sequencing giving products $474 \mathrm{bp}$ long. The average percentage of nucleotide composition for the partial fragment was: $30.17 \%(\mathrm{~A}), 6.12 \%(\mathrm{C})$, $17.09 \%(\mathrm{G})$, and $46.62 \%(\mathrm{~T})$. The $\mathrm{G}+\mathrm{C}$ content were $23.21 \%$. The consensus nucleotide sequence was submitted in the GenBank database under the accession number MH374631. Demodex canis (isolate DP-Samsun, MH374631) from Turkey matched 100\% (474/474) previously reported gene sequences for the mtDNA $12 \mathrm{~S}$ rRNA in $D$. canis (KX264486, isolate Demo.can2) from dogs in China (Hu et al. 2017). Moreover, D. canis isolate DP-Samsun from Turkey (MH374631) showed 99.2 to $99.8 \%$ identities with $D$. canis (isolate Demo.can3, KX264487 and Demo.can4, KX264488) from China according to $12 \mathrm{~S}$ region (Hu et al. 2017). We herein report that our sequence (MH374631) differed by three 
polymorphic sites (alignment positions 28, 33 and 257 ) with the sequences of $D$. canis isolate Demo.can3 (KX264487) and one nucleotide (alignment position 210) in the mtDNA 12S rRNA sequence of $D$. canis isolate Demo.can4 (KX264488) from the China (Hu et al. 2007). Pairwise comparison between the mtDNA 12S rRNA sequences of the $D$. canis from Turkey (MH374631) and other D. canis isolates from China (KX264486-88) presented differences ranging from 0.0 to $0.6 \%$.

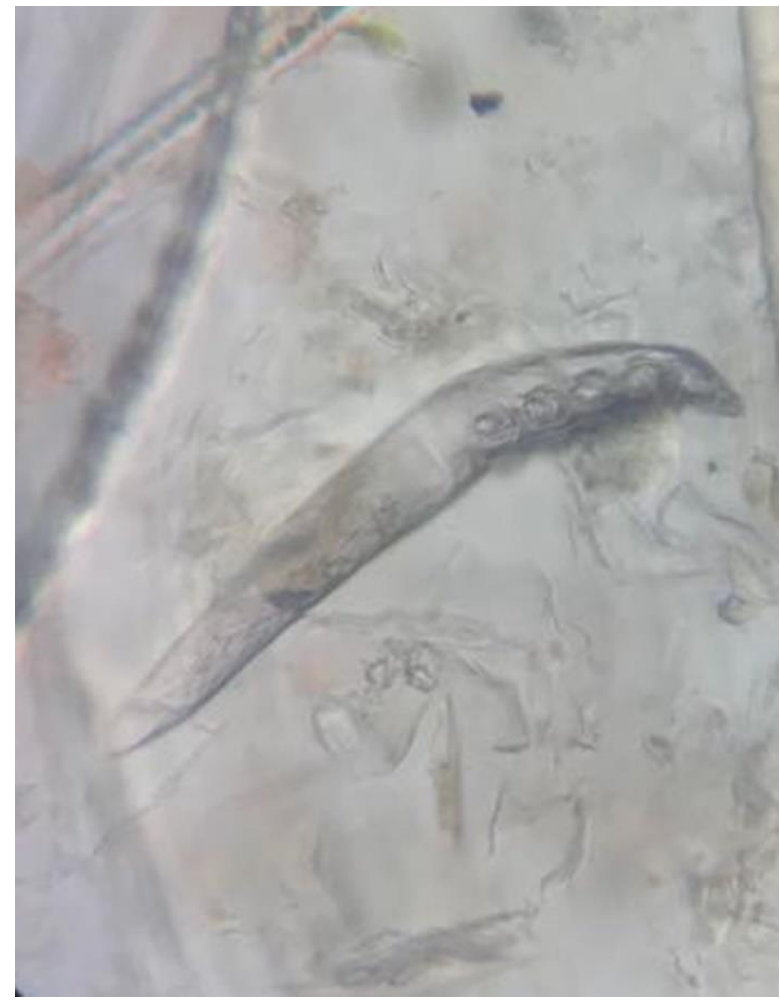

Figure 1: Microscopic image of Demodex canis mite (original).

\section{DISCUSSION}

For a long while classification of Demodex mites has relied on hosts and morphological characteristics. Interestingly, the morphological characteristics of Demodex mites are prone to the influence of environment which may lead to different classifications of phenotypes. Additionally, different Demodex species might coexist in the host and cause difficulty in species differentiation (Zhao et al. 2013). Successfully, in the last decade DNA barcoding techniques support a useful achievement for the molecular characterization of Demodex species in animals (Zhao et al. 2014). The mitochondrial genes have a maternal inheritance, rapid evolution and various evolution rates for different regions have been most entirely provided in molecular characterization among the arthropod species (De et al. 2012, Frank et al. 2013, Zhao et al. 2013, 2014, Silbermayr et al. 2015; Sastre et al.
2016). Recently, the mtDNA $12 \mathrm{~S}$ is proved to be used more suitable than the other DNA barcoding gene for molecular characterization of Demodecid mites (Hu et al. 2017). Therefore, molecular identification and characterization of $D$. canis has also proved by molecular evidence inferred from a mitochondrial $12 \mathrm{~S}$ marker used in the current study. In Turkey, Demodex species was only morphologically reported from different companion animals (Deger et al. 1994, Beyazit et al. 2010, Maden et al. 2012, Pekmezci et al. 2014). However, to date, there is no molecular identification of Demodex species in Turkey. Furthermore, within the present study, we also provide the first molecular evidence of $D$. canis in domestic dogs.

In conclusion, present study confirms that mitochondrial $12 \mathrm{~S}$ partial sequence is a useful tool to discriminate $D$. canis isolate from domestic dog in Turkey as previously reported by Hu et al (2017). Therefore, mitochondrial 12S-based identification in Demodicidae should also be used in the other domestic and livestock animals in Turkey.

\section{REFERENCES}

Altschul SF, Gish W, Miller W, Myers EW, Lipman DJ. Basic local alignment search tool. J. Mol. Biol. 1990; 215: 403-410.

Beyazit A, İnceboz T, Över L. Tek tıp, tek sağlik konseptine katkı: Demodicosisli bir köpek. Turkiye Parazitol. Derg. 2010; 34(1), 68-71.

Cheng J, Liu CC, Zhao YE, Hu L, Yang YJ, Yang F, Shi ZY. Population identification and divergence threshold in Psoroptidae based on ribosomal ITS2 and mitochondrial cox1 genes. Parasitol. Res. 2015; 114: $3497-$ 3507.

De RM, Riazzo C, Callejón R, Guevara D, Cutillas C. Morphobiometrical and molecular study of two populations of Demodex folliculorum from humans. Parasitol. Res. 2012; 110: 227-233.

Deger S, Tascı S, Akgül Y, Alkan İ. Van ve yöresinde evcil hayvanlarda ektoparaziter dermatitisler. Y. Y. Üniv. Vet. Fak. Derg. 1994; 5(1): 155-161.

Frank LA, Kania SA, Chung K, Brahmbhatt R. A molecular technique for the detection and differentiation of Demodex, mites on cats. Vet. Dermatol. 2013; 24: 82-83.

Hall TA. BioEdit: a user-friendly biological sequence alignment editor and analysis program for Windows 95/98/NT. Nucleic Acids Symp. Ser. 1999; 41: 95-98. 
Hu L, Yang Y, Zhao Y, Niu D, Yang R, Wang $\mathbf{R}, \mathbf{L i} \mathbf{X}$. DNA barcoding for molecular identification of Demodex based on mitochondrial genes. Parasitol. Res. 2017; 116(12): 3285-3290.

Izdebska JN, Rolbiecki L. The status of Demodex cornei: description of the species and developmental stages, and data on demodecid mites in the domestic dog Canis lupus familiaris. Medical and Vet. Entomol. 2018; https://doi.org/10.1111/mve.12304.

Kearse M, Moir R, Wilson A, Stones-Havas S, Cheung M, Sturrock S, Buxton S, Cooper A, Markowitz S, Duran C, Thierer T, Ashton B, Mentjies P, Drummond A. Geneious Basic: an integrated and extendable desktop software platform for the organization and analysis of sequence data. Bioinformatics 2012; 28(12): $1647-$ 1649.

Kumar S, Stecher G, Tamura K. MEGA7: molecular evolutionary genetics analysis version 7.0 for bigger datasets. Mol. Biol. Evol. 2016; 33: 1870-1874.

Maden M, Er C, Kav, K, Özdemir Ö. İngiliz pointer ırkı bir köpekte Demodex canis kökenli atipik dermatitis olgusunun başarılı sağaltımı. Kafkas Üniv. Vet. Fak. Derg. 2012; 18(6): 1073-1077.

Pekmezci D, Pekmezci GZ, Guzel M, Cenesiz S, Gurler AT, Gokalp G. Efficacy of amitraz plus inactivated parapoxvirus ovis in the treatment of canine generalised demodicosis. Vet. Rec. 2014; 174(22): 556556.

Sastre N, Francino O, Curti JN, Armenta TC, Fraser DL, Kelly RM, Hunt E, Silbermayr K, Zewe C, SaÂnchez A, Ferrer L. Detection, prevalence and phylogenetic relationships of Demodex spp and further skin prostigmata mites (Acari, Arachnida) in wild and domestic mammals. PLoS One 2016; 11:e0165765.

Scott DW, Miller WM, Griffin CE (2001) Parasitic Skin Diseases, In: Muller and Kirk's Small Animal Dermatology, Ed; Di Berardino C, 6 ${ }^{\text {th }}$ Ed., W.B. Saunders Company, Philadelphia, USA. pp. 423-516.

Silbermayr K, Horvath-Ungerboeck C, Eigner B, Joachim A, Ferrer L. Phylogenetic relationships and new genetic tools for the detection and discrimination of the three feline Demodex mites. Parasitol. Res. 2015; 114(2): 747-752.
Simon C, Frati F, Beckenbach AT, Crespi B, Liu H, Flook P. Evolution, weighting and phylogenetic utility of mitochondrial gene sequences and a compilation of conserved polymerase chain reaction primers. Entomol. Soc. Am. 1994; 87: 651-701.

Thompson JD, Higgins DG, Gibson TJ. CLUSTAL W: improving the sensitivity of progressive multiple sequence alignment through sequence weighting, positionspecific gap penalties and weight matrix choice. Nucleic Acids Res. 1994; 22: $4673-$ 4680.

Zhao YE, Cheng J, Hu L, Ma JX. Molecular identification and phylogenetic study of Demodex caprae. Parasitol. Res. 2014; 113: 3601-3608.

Zhao YE, Hu L, Ma JX. Molecular identification of four phenotypes of human Demodex mites (Acari: Demodicidae) based on mitochondrial 16S rDNA. Parasitol. Res. 2013; 112(11): 3703-3711. 